\title{
Improving Nutrient and Organic Matter Removal by Novel Integration of a High-Rate Algal Pond and Submerged Macrophyte Pond
}

\author{
Yi Ding ${ }^{1,2}$, Yuhui Wang ${ }^{2}$, Xingpo Liu ${ }^{1}$, Xinshan Song ${ }^{2 *}$ \\ ${ }^{1}$ College of Ocean Science and Engineering, Center for Marine Environmental and Ecological Modelling, \\ Shanghai Maritime University, Shanghai, China \\ ${ }^{2}$ College of Environmental Science and Engineering, State Environmental Protection Engineering Center for Pollution \\ Treatment and Control in Textile Industry, Donghua University, Shanghai, China
}

Received: 10 October 2018

Accepted: 18 November 2018

\begin{abstract}
This study investigated the remediation effect of a high-rate algal pond (HRAP) and submerged macrophyte pond (SMP) on nutrient and organic matter removal, and explored the effect of SMP on ecological elimination of algae biomass. The results showed that submerged macrophytes could be effective in inhibiting flourishing algae growth. An HRAP-SMP hybrid system exhibited better removal performance than single HRAP and SMP reactor, and $45.6 \pm 2.0 \% \mathrm{TN}, 99.0 \pm 1.0 \% \mathrm{TP}$ and $99.0 \pm 1.0 \%$ DCOD was reduced in the hybrid system. This study demonstrated that the novel integration of HRAP and SMP could be a promising solution for efficient removal of nutrient and organic matter.
\end{abstract}

Keywords: high-rate algal pond, submerged macrophyte pond, algae inhibition, nutrient and organic matter removal

\section{Introduction}

Untreated wastewaters are often characterized by their high nutrient and organic matter loads, which consequently cause eutrophication of water bodies [1]. It is increasingly recognized that wastewater should be treated in an ecological and sustainable way for improving water quality. Conventional treatment techniques entail high investment and operational costs [2]. In this regard, algae-based technologies exhibit great promise for wastewater treatment due to their cost-

*e-mail: newmountain@dhu.edu.cn effectiveness and high-quality effluent [3-4]. A high-rate algal pond (HRAP) has been developed for microalgae cultivation in which a large quantity of wastewater can be treated [5]. Algae can utilize nutrients and high levels of organic carbon from wastewater for its flourishing growth, thus contributing to water purification [6].

However, surplus algae in the effluent will pose great threats to people's lives and production [7]. Therefore, control and elimination of algae biomass has been a significant goal in the aquatic ecosystem. The mechanical removal of algae biomass is impractical while the chemical treatment is undesirable in potable water supplies [8]. The allelopathic inhibition of submerged macrophytes on algae growth is extremely promising due to its low cost and high 
environmental safety. Previous studies have reported that Ceratophyllum demersum, Myriophyllum spicatum and Vallisneria natans could inhibit growth of microalgae by releasing allelochemicals into water [911]. Furthermore, submerged macrophytes play an important role in the restoration of lakes suffering from excessive nutrient and organic matter inputs. Submerged macrophytes growing under water provide higher root surface area for microbial growth. They not only absorb high amounts of nutrients but also provide nutrients and oxygen for microbes [12]. Microbial nitrificationdenitrification has the most dominant effect on overall nitrogen removal [13]. Oxygen transfer by macrophytes into the root zone plays a significant role in promoting the nitrification process and supporting aerobic bacteria degradation of organics in the wastewater. In summary, submerged macrophytes can contribute to keeping a healthy aquatic ecosystem. Therefore, it is reasonable to use a submerged macrophyte pond (SMP) for deeppurifying HRAP effluents.

In this study, the integration of HRAP and SMP provide a novel and cost-effective treatment system for water purification. However, information on the integration of HRAP and SMP as well as their synergistic effect on nutrient and organic matter removals was unknown. In addition, insufficient knowledge about the operating mode of the hybrid system impeded the optimization of the hybrid system. The study aims to evaluate the variations of algae biomass, nutrient and organic matter in experimental units (single HRAP, single SMP, and hybrid system), evaluate the effect of SMP on optimization of HRAP effluent quality, discuss the effect of hydraulic retention time (HRT) on the performance of hybrid systems, and obtain the optimal operating mode for enhancing nutrient and organic matter removal.

\section{Material and Methods}

The present study was conducted in four labscale HRAP-SMP hybrid systems located outdoors at Donghua University, Shanghai, China $\left(38^{\circ} 39^{\prime} 27^{\prime \prime} \mathrm{N}\right.$, $\left.104^{\circ} 04^{\prime} 58^{\prime \prime} \mathrm{E}\right)$. The dimensions $(\mathrm{L} \times \mathrm{W} \times \mathrm{D})$ of the HRAP and SMP reactor were identical at $0.96 \times 0.60 \times 0.60 \mathrm{~m}$, and the total working volume was $300 \mathrm{~L}$. Each HRAP was a single-loop raceway separated by a central baffle, and wastewater in the pond channel was circulated at a velocity of $0.18 \pm 0.02 \mathrm{~m} \mathrm{~s}^{-1}$ by a mechanical stirrer. Algae species Microcystis aeruginosa was obtained from the Institute of Hydrobiology at the Chinese Academy of Sciences, and chlorophyll a (Chl-a) content was determined as an indicator of algae biomass. Synthetic domestic wastewater with tap water was added into experimental units from inlet tanks by peristaltic pumps, and the total inflow was $250 \pm 5 \mathrm{~L}$ within $1 \mathrm{~h}$. Table 2 shows the composition of the influent wastewater.

The bottom of the SMP reactor was filled with a $10 \mathrm{~cm}$ thick layer of fine gravel $(\Phi=1.5-2.0 \mathrm{~cm})$, above which was filled with a $5 \mathrm{~cm}$ thick layer of washed sand $(\Phi<0.2 \mathrm{~cm})$ to facilitate macrophyte growth. Perennial submerged macrophytes of Vallisneria natans were collected from Chen Shan Botanical Garden, Shanghai, China $\left(31^{\circ} 04^{\prime} 37.28^{\prime \prime} \mathrm{N}, 121^{\circ} 10^{\prime} 42.76^{\prime \prime} \mathrm{E}\right)$, which is widely present infreshwater habitats and eutrophic lakes. Macrophytes with uniform growth $(35 \pm 5 \mathrm{~cm})$ and similar biomass $(30 \pm 5 \mathrm{~g})$ were selected. The same plant density $\left(7.5 \pm 0.5 \mathrm{~g} \mathrm{~L}^{-1}\right)$ was maintained.

Experiments were performed in triplicate, and average temperature in the experimental phase(June to October) was 20 to $35^{\circ} \mathrm{C}$. Experiments were carried out in single HRAP (Fig. 1a), single SMP (Fig. 1b) and hybrid systems A and B (Fig. 1c). HRT of four experimental systems were $3 \mathrm{~d}$. Of these, single HRAP and SMP were individually operated in an intermittent way with 3d-HRT. Hybrid system A was

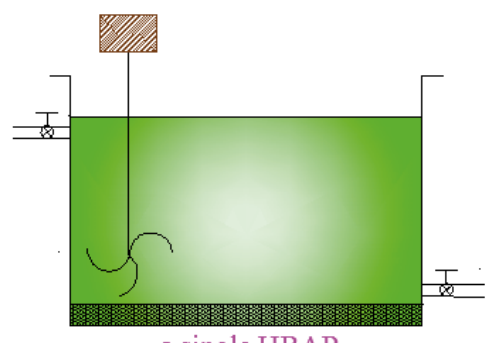

a.single HRAP

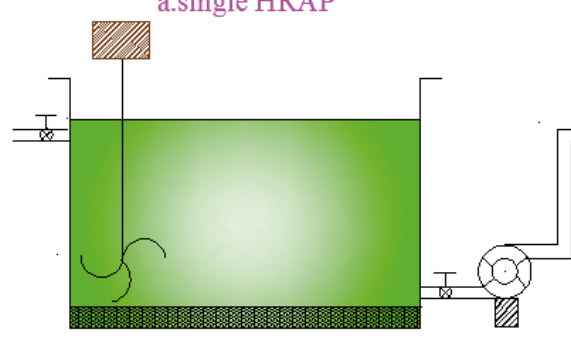

c.hybrid system
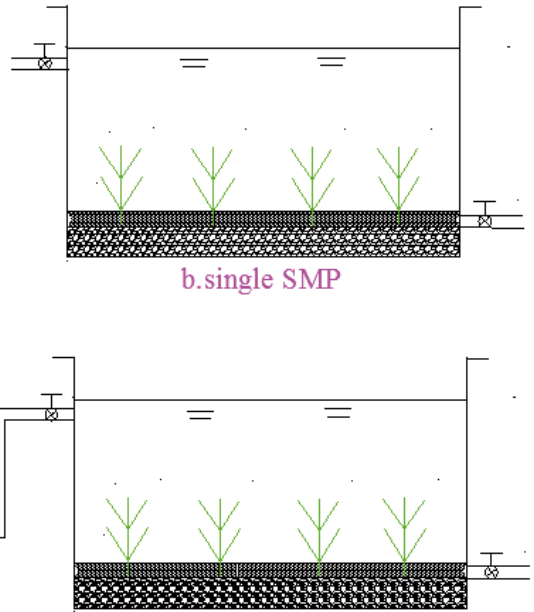

Fig. 1. Schematic diagram of experimental units: single HRAP a), single SMP b), and hybrid system c). 
Table 1. Variations of algae concentration with HRT in four experimental systems.

\begin{tabular}{|c|c|c|c|c|}
\hline \multirow{2}{*}{ Systems } & \multirow{2}{*}{ Influent algae content $\left(\right.$ cells $\left.\mathrm{mL}^{-1}\right)$} & \multicolumn{3}{|c|}{ Effluent algae content $\left(\right.$ cells $\left.\mathrm{mL}^{-1}\right)$} \\
\cline { 3 - 4 } & & $1 \mathrm{~d}-\mathrm{HRT}$ & $2 \mathrm{~d}-\mathrm{HRT}$ & $3 \mathrm{~d}-\mathrm{HRT}$ \\
\hline Single HRAP & $580 \pm 100$ & $2652 \pm 100$ & $13235 \pm 200$ & $24155 \pm 200$ \\
\hline Single SMP & $580 \pm 100$ & $2032 \pm 100$ & $6787 \pm 200$ & $8034 \pm 200$ \\
\hline Hybrid system A & $580 \pm 100$ & $2750 \pm 100$ & $9212 \pm 200$ & $12508 \pm 200$ \\
\hline Hybrid system B & $580 \pm 100$ & $2685 \pm 100$ & $12952 \pm 200$ & $19085 \pm 200$ \\
\hline
\end{tabular}

operated in an intermittent way with 1d-HRT of HRAP and 2d-HRT of SMP. Hybrid system B was operated in an intermittent way with 2d-HRT of HRAP and 1d-HRT of SMP.

Chl-a content was immediately measured in situ after using a portable water quality multi- probe (Manta 2, EURERA, USA). Total nitrogen (TN, Persulfate Digestion Method), ammonia nitrogen $\left(\mathrm{NH}_{4}-\mathrm{N}\right.$, Nessler's Reagent Spectrophotometry), nitrate $\left(\mathrm{NO}_{3}-\mathrm{N}\right.$,
UV Spectrophotometric Determination), dissolved reactive phosphorus (DRP, Acid Persulfate Reduction Method), total phosphorus (TP, Acid Persulfate Reduction Method) and dissolved chemical oxygen demand (DCOD, Potassium Dichromate Method) were measured using a multi-parameter colorimeter (DR900, $\mathrm{HACH}, \mathrm{USA})$ [14]. The samples were filtered through glassfiber filters $(0.22 \mu \mathrm{m})$ for analysis. All data are presented as mean \pm SD. Statistical analyses were

Table 2. Pollutant removal performance of the four experimental systems.

\begin{tabular}{|c|c|c|c|c|}
\hline Parameters & Influent ( $\left.\mathrm{mg} \mathrm{L}^{-1}\right)$ & System & Effluent $\left(\mathrm{mg} \mathrm{L}^{-1}\right)$ & Removal (\%) \\
\hline \multirow{4}{*}{$\mathrm{NH}_{4}-\mathrm{N}$} & \multirow{4}{*}{$24.0 \pm 1.0$} & Single HRAP & $13.7 \pm 0.5$ & $42.9 \pm 2.0$ \\
\hline & & Single SMP & $12.5 \pm 0.5$ & $47.9 \pm 2.0$ \\
\hline & & Hybrid system A & $11.4 \pm 0.5$ & $52.5 \pm 2.0$ \\
\hline & & Hybrid system B & $12.0 \pm 0.5$ & $50.0 \pm 2.0$ \\
\hline \multirow{4}{*}{$\mathrm{NO}_{3}-\mathrm{N}$} & \multirow{4}{*}{$0.1 \pm 0.1$} & Single HRAP & $0.7 \pm 0.2$ & -- \\
\hline & & Single SMP & $3.0 \pm 0.2$ & -- \\
\hline & & Hybrid system A & $2.5 \pm 0.2$ & -- \\
\hline & & Hybrid system B & $1.5 \pm 0.2$ & -- \\
\hline \multirow{4}{*}{$\mathrm{TN}$} & \multirow{4}{*}{$25.2 \pm 1.0$} & Single HRAP & $14.9 \pm 0.5$ & $40.9 \pm 2.0$ \\
\hline & & Single SMP & $15.7 \pm 0.5$ & $37.7 \pm 2.0$ \\
\hline & & Hybrid system A & $14.2 \pm 0.5$ & $43.7 \pm 2.0$ \\
\hline & & Hybrid system B & $13.7 \pm 0.5$ & $45.6 \pm 2.0$ \\
\hline \multirow{4}{*}{ DRP } & \multirow{4}{*}{$5.40 \pm 0.5$} & Single HRAP & $1.14 \pm 0.2$ & $78.9 \pm 1.0$ \\
\hline & & Single SMP & $0.25 \pm 0.2$ & $95.4 \pm 1.0$ \\
\hline & & Hybrid system A & $0.1 \pm 0.1$ & $99.0 \pm 1.0$ \\
\hline & & Hybrid system B & $0.1 \pm 0.1$ & $99.0 \pm 1.0$ \\
\hline \multirow{4}{*}{ TP } & \multirow{4}{*}{$5.80 \pm 0.5$} & Single HRAP & $1.30 \pm 0.2$ & $77.6 \pm 1.0$ \\
\hline & & Single SMP & $0.33 \pm 0.2$ & $94.3 \pm 1.0$ \\
\hline & & Hybrid system A & $0.1 \pm 0.1$ & $99.0 \pm 1.0$ \\
\hline & & Hybrid system B & $0.1 \pm 0.1$ & $99.0 \pm 1.0$ \\
\hline \multirow{4}{*}{ DCOD } & \multirow{4}{*}{$80.0 \pm 4.0$} & Single HRAP & $1.0 \pm 1.0$ & $99.0 \pm 1.0$ \\
\hline & & Single SMP & $18.0 \pm 3.0$ & $77.5 \pm 2.0$ \\
\hline & & Hybrid system A & $8.0 \pm 2.0$ & $90.0 \pm 2.0$ \\
\hline & & Hybrid system B & $1.0 \pm 1.0$ & $99.0 \pm 1.0$ \\
\hline
\end{tabular}


performed with Origin 8.0 (Origin Lab, MA, USA) statistical software, and significant differences among treatment means $(p<0.01)$ were determined by Student's $t$ test.

\section{Results and Discussion}

During 3 days of treatment, the variations of algae concentration with HRT in four experimental systems are shown in Table 1. Fig. 2 presents the profiles of Chl-a, DCOD, TP and TN in experimental units. As demonstrated by Table 1 and Fig. 2a), algae content in single HRAP increased sharply, whereas it increased gradually in the other three systems followed by a slight fluctuation. The main reason for this phenomenon was the function of submerged macrophytes in SMP. Effluent algae content of single SMP at 3d-HRT $\left(8034 \pm 200\right.$ cells $\left.\mathrm{mL}^{-1}\right)$ was significantly lower than that $\left(24155 \pm 200\right.$ cells $\left.\mathrm{mL}^{-1}\right)$ in single HRAP $(p<0.01)$. The results impliedthat submerged macrophytes could be effective in inhibiting algae flourishing growth. Hybrid systems A and B were operated with different HRT modes. Effluent algae content of hybrid system A at 3d-HRT $\left(12508 \pm 200\right.$ cells $\left.\mathrm{mL}^{-1}\right)$ was significantly lower than that $\left(19085 \pm 200\right.$ cells $\left.\mathrm{mL}^{-1}\right)$ in hybrid system B $(p<0.01)$, which was attributed to the longer retention time of wastewater in SMP. In conclusion, it is feasible to use SMP for controlling and decreasing surplus algae from HRAP effluents.

DCOD value gradually declined with HRT in experimental systems (Fig. 2b). Pollutant removal performance of experimental units was presented in Table 2. As presented in Table 2, average DCOD removal in single HRAP and hybrid system B after 3d-HRT was over $99.0 \%$, which was higher than that in single SMP $(77.5 \pm 2.0 \%)$ and hybrid system A $(90.0 \pm 2.0 \%)$. The main reason was that dissolved organic matter released from submerged macrophytes led to poor DCOD removal [15]. Hybrid system B exhibited the higher DCOD removal than hybrid System A, which was ascribed to the longer retention time of wastewater in HRAP.

Phosphorus removal mechanisms in the hybrid system include algae assimilation, sedimentation, macrophyte uptake and microbial adsorption [16]. Macrophytes can effectively remove nutrients and play an important part in the restoration of eutrophic waters [17]. As shown in Table 2 and Fig. 2c), reductions in DRP and TP were more significant in hybrid systems $\mathrm{A}$ and $\mathrm{B}(p<0.01)$ due to the integrated mechanisms for phosphorus removal, where average DRP and TP removal was over 99.0\%. Phosphorus removal performance of single SMP was significantly higher than that of single HRAP $(p<0.01)$ due to the high adsorption capacity of Vallisneria natans. In summary, besides microbial mechanisms, macrophyte uptake could be an important phosphorus removal pathway.

Algae assimilation and ammonia volatilization are the main $\mathrm{N}$ removal mechanism of HRAP, while macrophyte uptake and microbial nitrificationdenitrification represents $\mathrm{N}$ removal pathway of SMP [18-19]. As demonstrated in Table 2 and Fig. 2d), TN concentration decreased gradually with HRT in experimental units. $\mathrm{NH}_{4}-\mathrm{N}$ removal performance of single SMP was better than that of single HRAP, whereas single HRAP exhibited higher TN removal than single SMP. $\mathrm{NH}_{4}-\mathrm{N}$ and $\mathrm{TN}$ removal in single SMP were respectively $47.9 \pm 2.0 \%$ and $37.7 \pm 2.0 \%$, and effluent $\mathrm{NO}_{3}-\mathrm{N}$ concentration reached $3.0 \pm 0.2 \mathrm{mg} \mathrm{L}^{-1}$. The main reason for this phenomenon was the limitation of microbial denitrification leading to poor $\mathrm{TN}$ removal of single SMP. Dissolved oxygen was abundant in single SMP due to photosynthetic macrophytes and algae, which created more favorable conditions for nitrification occurring in oxidized root zone of macrophytes and

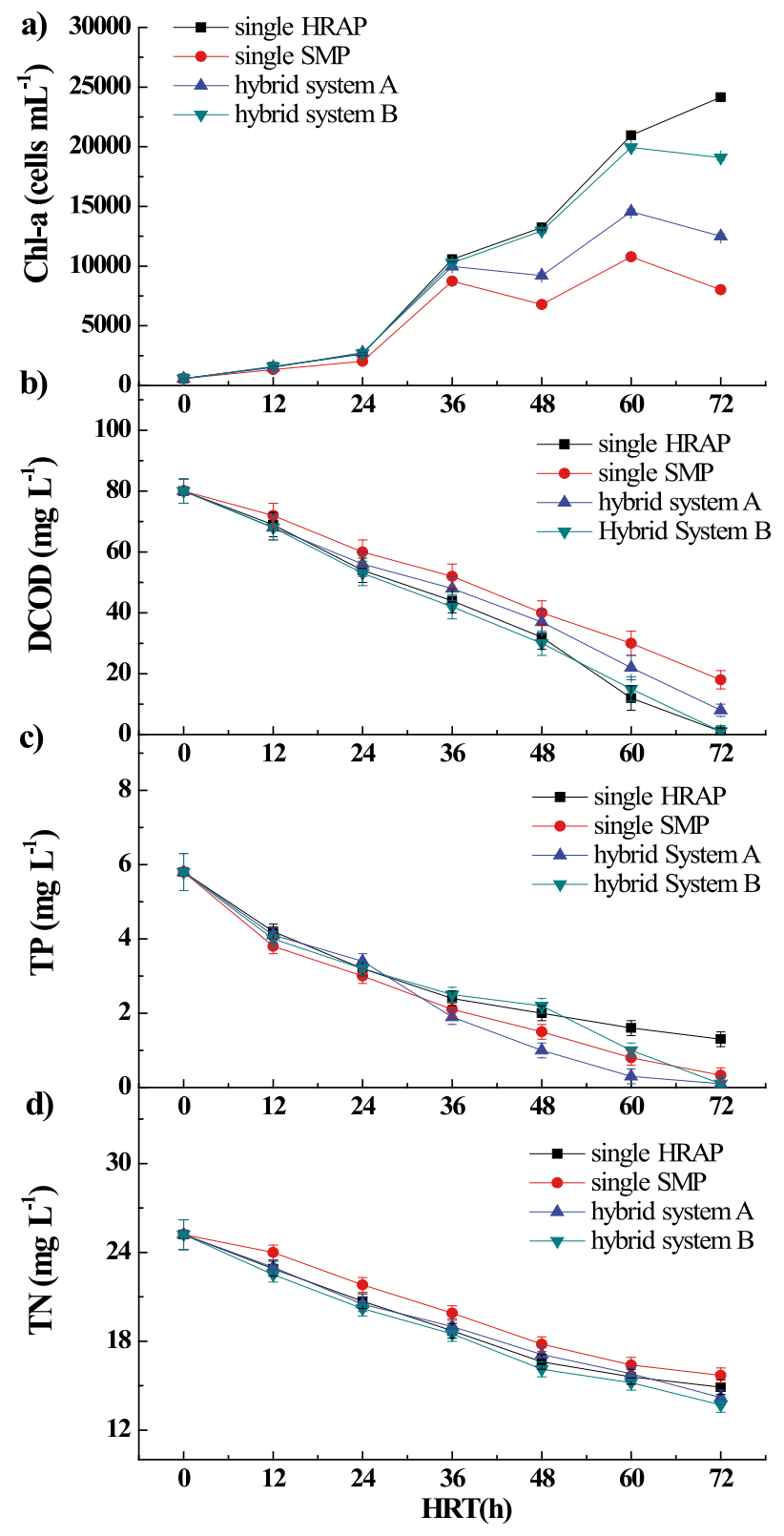

Fig. 2. Profiles of Chl-a a), DCOD b), TP c), and TN d) in experimental units. 
inhibited the occurrence of denitrification. Accumulated $\mathrm{NO}_{3}-\mathrm{N}$ could be partly assimilated by submerged macrophytes, whereas residual $\mathrm{NO}_{3}-\mathrm{N}$ influenced $\mathrm{TN}$ removal. $\mathrm{NH}_{4}-\mathrm{N}$ and $\mathrm{TN}$ reduction in hybrid systems was higher than that in the single HRAP and SMP reactor due to the integrated mechanisms for nitrogen removal. The optimal elimination of $\mathrm{NH}_{4}-\mathrm{N}(52.5 \pm 2.0 \%)$ and TN $(45.6 \pm 2.0 \%)$ was observed in the hybrid system.

\section{Conclusions}

SMP was combined with HRAP for deep purifying HRAP effluents and ecological control of surplus algae. The results demonstrated that SMP is an effective strategy for algae elimination. Better nutrient and organic matter removal performance was obtained in the hybrid system due to the integrated mechanisms for pollutant removal. The novel integration of HRAP and SMP offers more efficient and economical operation process for high-quality effluent. The study may provide an effective option for improving nutrient and organic matter removal from wastewater.

\section{Acknowledgements}

This study was supported by the National Natural Science Foundation of China (grant Nos. 51809162 and 51679041) and the Fundamental Research Funds for the Central Universities (grant No. 18D111310).

\section{Conflict of Interest}

The authors declare no conflict of interest.

\section{References}

1. YE C.B., ZHOU Z.M., LI M., LIU Q., XU T.T., LI J. Evaluation of simultaneous organic matters and nutrients removal from municipal wastewater using a novel bioreactor $\left(\mathrm{D}-\mathrm{A}^{2} \mathrm{O}\right)$ system. J. Environ. Manage., 218, 509, 2018.

2. POSADAS E., GARCÍA-ENCINA P.-A., SOLTAUA., DOMÍNGUEZ A., DÍAZ I., MUNOZ R. Carbon and nutrient removal from centrates and domestic wastewater using algal-bacterial biofilm bioreactors. Bioresour. Technol., 139, 50, 2013.

3. CHENG J., YE Q., XU J., YANG Z.B., ZHOU J.H., CEN $\mathrm{K}$. Improving pollutants removal by microalgae Chlorella $P Y$-ZU1 with $15 \% \mathrm{CO}_{2}$ from undiluted anaerobic digestion effluent of food wastes with ozonation pretreatment. Bioresour. Technol., 216, 273, 2016.

4. LV J.P., GUO J.Y., FENG J., LIU Q., XIE S.L. A comparative study on flocculating ability and growth potential of two microalgae in simulated secondary effluent Bioresour. Technol., 205, 111, 2016.
5. SUTHERLAND D.L., HOWARD-WILLIAMS C., TURNBULL M.H., BROADY P.A., CRAGGS R.J. Enhancing microalgal photosynthesis and productivity in wastewater treatment high rate algal ponds for biofuel production. Bioresour. Technol., 184, 222, 2015.

6. USHA M.T., CHANDRA T.S., SARADA R., CHAUHAN V.S. Removal of nutrients and organic pollution load from pulp and paper mill effluent by microalgae in outdoor open pond. Bioresour. Technol., 214, 856, 2016.

7. HUANG J., GRAHAM N., TEMPLETON M.R., ZHANG Y., COLLINS C., NIEUWENHUIJSEN M. A comparison of the role of two blue-green algae in THM and HAA formation. Water Res., 43 (12), 3009, 2009.

8. BALL A.S., WILLIAMS M., VINCENT D., ROBINSON J. Algal growth control by a barley straw extract. Bioresour. Technol., 77 (2), 177, 2001.

9. GAO Y.-N., LIU B.-Y., XU D., ZHOU Q.-H., HU C.-Y., GE F.-J., ZHANG L.-P., WU Z.-B.. Phenolic compounds exuded from two submerged freshwater macrophytes and their allelopathic effects on Microcystis aeruginosa. Pol. J. Environ. Stud., 20 (5), 1153, 2011.

10. GROSS E.M., ERHARD D., IVÁNYI E. Allelopathic activity of Ceratophyllum demersum L. and Najas marina ssp. intermedia (Wolfgang) Casper. Hydrobiologia, 506 (13), 583, 2003.

11. NAKAI S., YAMADA S., HOSOMI M. Anticyanobacterial fatty acids released from Myriophyllum spicatum. Hydrobiologia, 543 (1), 71, 2005.

12. MOHAN S.V., MOHANAKRISHNA G., CHIRANJEEVI P., PERI D., SARMA P.N. Ecologically engineered system (EES) designed to integrate floating, emergent and submerged macrophytes for the treatment of domestic sewage and acidrich fermented-distillery wastewater: Evaluation of long term performance. Bioresour. Technol., 101, 3363, 2010.

13. SONG Y.-Z., WANG J.-Q., GAO Y.-X., XIE X.-J. The physiological responses of Vallisneria natans to epiphyticalgae with the increase of $\mathrm{N}$ and $\mathrm{P}$ concentrations in water bodies. Environ. Sci. Pollut. Res., 22, 8480, 2015.

14. ZHAO Z.M., SONG X.S., XIAO Y.P., ZHAO Y.F., GONG Z.J., LIN F.D., DING Y., WANG W., QIN T.L. Influences of seasons, N/P ratios and chemical compounds on phosphorus removal performance in algal pond combined with constructed wetlands. Sci. Total Environ.,573, 906, 2016.

15. LIU S.S., ZHAO T.H., ZHU Y.R., QU X.X., HE Z.Q., GIESY J.P., MENG W. Molecular characterization of macrophyte-derived dissolved organic matters and their implications for lakes. Sci. Total Environ., 616-617, 602, 2018.

16. WANG J.L., CHEN G.F., LIU F.X., SONG X.F., ZOU G.Y. Combined ozonation and aquatic macrophyte (Vallisneria natans)treatment of piggery effluent: Water matrix and antioxidant responses. Ecol. Eng., 102, 39, 2017.

17. MA L., HE F., SUN J., WANG L., XU D., WU Z.B. Remediation effect of pond-ditch circulation on rural wastewater insouthern China. Ecol. Eng., 77, 363, 2015.

18. MA L., HE F., HUANG T., ZHOU Q.H., ZHANG Y., WU Z.B. Nitrogen and phosphorus transformations and balance in a pond-ditch circulation system for rural polluted water treatment. Ecol. Eng., 94, 117, 2016.

19. PARK J.B.K., CRAGGS R.J., SHILTON A.N. Wastewater treatment high rate algal ponds for biofuel production. Bioresour. Technol., 102, 35, 2011. 